\section{MS16-O3 New coordination chemistry and properties revealed by high pressure crystallography}

Alexander J. Blake ${ }^{1}$, Jeremiah P. Tidey ${ }^{1}$, Alice E. O'Connor ${ }^{1}$, Jonathon McMaster ${ }^{1}$, Martin Schröder ${ }^{1,2}$, David R. Allan ${ }^{3}$

1. University of Nottingham

2. University of Manchester

3. Diamond Light Source

email: a.j.blake@nottingham.ac.uk

The results of our initial experiments in high pressure crystallography provided vital signposts for our subsequent studies, leading to the discovery of unusual and usually unpredicted phenomena. The coordination compounds we have studied under pressure include macrocyclic complexes of thioether [1-3] and oxathioether [4, 5] ligands, cyclometallated $\mathrm{Pt}(\mathrm{II})$ complexes, gold complexes [7] and extended polyiodides.

For example, we studied the salt $\left[\mathrm{Ag}\left([18] \mathrm{aneS}_{6}\right)\right] \mathrm{I}_{7}$ which is known to adopt a highly unusual and visually striking structure [8] - see Figure 1. The complex cation templates the formation of a distorted cubic cage consisting of iodine molecules $\left(\mathrm{I}_{2}\right)$ and iodide ions $\left(\mathrm{I}^{-}\right)$. The iodines and iodides form an extended polymeric matrix in which the cations reside. In response to moderate pressure, $\left[\operatorname{Ag}\left([18] \mathrm{aneS}_{6}\right)\right] \mathrm{I}_{7}$ undergoes a distinct phase change involving desymmetrisation of the cubic cage and the evolution of a discrete $\mathrm{I}_{7}{ }^{-}$anion. The resulting phase is stable over the pressure range 11-36 kbar.

This contribution will describe how pressure can effect significant changes to coordination complexes, including to their structures, conformations, spectroscopic properties and degrees of association.

\section{References}

1. D. R. Allan, A. J. Blake, D. Huang, T. J. Prior, M. Schröder, Chem. Commun. 2006, 4081.

2. D. R. Allan, D. Bailey, N. Bird, A. J. Blake, N. R. Champness, D. Huang, C. P. Keane, J. McMaster, T. J. Prior, J. P. Tidey, M. Schröder, Acta Crystallogr., Sect. B 2014, 70, 469.

3. H. L. S. Wong, D. R. Allan, N. R. Champness, J. McMaster, M. Schröder, A. J. Blake, Angew. Chem. Int. Ed. 2013, 52, 5093 .

4. J. P. Tidey, A. E. O'Connor, A. Markevich, E. Bichoutskaia, J. J. P. Cavan, G. A. Lawrance, H. L. S. Wong, J. McMaster, M. Schröder, A. J. Blake, Cryst. Growth Des. 2015, 15, 115.

5. J. P. Tidey, H. L. S. Wong, J. McMaster, M. Schröder, A. J. Blake, Acta Crystallogr., Sect. B, 2016, submitted.

6. J. P. Tidey, H. L. S. Wong, M. Schroder, A. J. Blake, Coord. Chem. Rev. 2014, 277-278, 187.

7. A. E. O'Connor, T. L. Easun, N. Mirzadeh, S. K. Bhargava, M. Schröder, A. J. Blake, ChemComm 2016, DOI: 10.1039/C6CC00923A.

8. A. J. Blake, R. O. Gould, S. Parsons, C. Radek, M. Schröder, Angew. Chem. Int. Ed. Engl. 1995, 34, 2374.

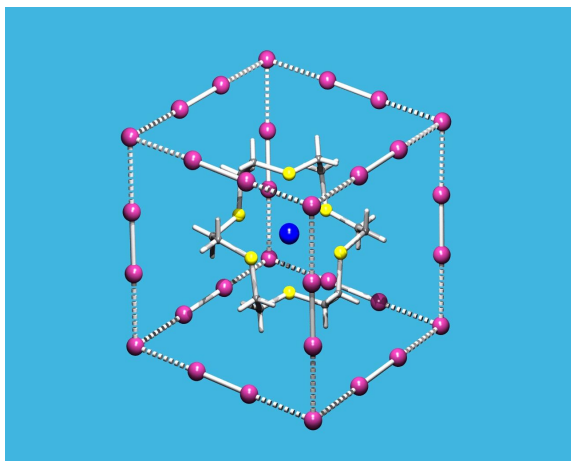

Figure 1. The complex cation in $[\operatorname{Ag}([18] \mathrm{aneS})] \mathrm{I}_{7}$ templates the formation of a distorted cube comprising iodine molecules and iodide ions.

Keywords: pressure dependence, spectroscopic properties, geometric distortion, conformation, disorder 